\title{
Retention of learned predator recognition in an endangered sucker Chasmistes liorus liorus
}

\author{
Stephanie K. Archer ${ }^{1,2, *}$, Todd A. Crowl ${ }^{1}$ \\ ${ }^{1}$ Utah State University, Ecology Center and Watershed Sciences Department, Logan, Utah 84322, USA \\ ${ }^{2}$ Present Address: Department of Applied Ecology, North Carolina State University, Raleigh, North Carolina 27695, USA
}

\begin{abstract}
Captive propagation and restocking of native fishes is a common conservation strategy. However, hatchery-reared fishes are predator-naïve, and thus many stocked fishes are lost to predation, reducing the effectiveness of restocking programs. Many fishes use odor to identify known predators and, through the detection of chemical alarm cues, learn to recognize novel predators. A large body of research has focused on the efficacy of using predator odors in conjunction with chemical alarm cues to train hatchery-reared fishes to recognize predators prior to stocking. While it appears possible to train most fishes to recognize a novel predator through exposure to olfactory cues, few studies have shown that this training translates into increased survival for trained fishes. Recently, it has been proposed that hatchery fishes do not retain the learned associations long enough for hatchery training to result in increased survival, though few studies have quantified how long hatchery-reared fishes do retain learned associations. We conducted a series of laboratory experiments that demonstrate hatchery-raised June sucker Chasmistes liorus liorus, an endangered sucker endemic to Utah Lake, Utah, USA, can learn to recognize a novel predator (largemouth bass Micropterus salmoides). We also show that this learned association is retained for at least $2 \mathrm{~d}$, but is lost by $10 \mathrm{~d}$ after initial exposure. Our results suggest that in the absence of reinforcement, June sucker do not retain learned predator recognition long enough to expect hatchery training to translate into increased survival.
\end{abstract}

KEY WORDS: June sucker · Chasmistes liorus liorus · Olfactory cues · Learning · Retention • Largemouth bass $\cdot$ Micropterus salmoides

\section{INTRODUCTION}

The loss of native species is a subject of concern for conservationists and ecosystem managers worldwide. Freshwater fishes are particularly threatened (Bruton 1995). In North America alone, there have been at least 42 documented extinctions of freshwater fish species and subspecies over the past 125 yr (Dextrase \& Mandrak 2006). Some estimates suggest $35 \%$ of fishes native to North America are currently threatened (Helfman 2007). Increasingly, conservation and management plans include restocking programs as a recovery tool (Marsh \& Brooks 1989, Rakes et al. 1999, Bearlin et al. 2002, Billman et al. 2011). However, there is strong evi-

\footnotetext{
*Corresponding author: skraftarcher@gmail.com
}

dence that hatchery fishes have lower survival than wild fishes, due to both genetic (Araki et al. 2007) and behavioral differences (e.g. Berejikian 1995, Pearsons et al. 2007, Yokota et al. 2007). The behavioral causes of hatchery fishes' reduced survival compared to their wild-born counterparts has led many to suggest training hatchery fishes in specific life skills, such as predator recognition, prior to their release (Brown \& Laland 2001, Fernö et al. 2011).

A large body of research has focused on the use of chemical alarm cues and other olfactory stimuli in predator recognition training (Brown et al. 2011a). Fishes use olfaction to identify a predation threat in 2 ways: through recognition of the odor of a predator, and through conspecific chemical alarm cues.

() The authors 2014. Open Access under Creative Commons by Attribution Licence. Use, distribution and reproduction are unrestricted. Authors and original publication must be credited. 
Chemical alarm cues were first documented by Karl von Frisch in 1938, who determined that the olfactory system mediated the reaction, and the alarm substance was stored in the skin (von Frisch 1938, 1942). These chemical alarm cues are released when the skin is broken, often during a predation event (Pfeiffer 1967). The release of an alarm substance allows conspecifics to initiate anti-predator defenses and to learn to identify new predators. There is wide support in the literature that fishes can learn to recognize novel predators by associating a predator's odor with the release of alarm cue (Brown et al. 2011a and references therein). The widespread ability of many fish species to use chemical cues to identify novel predators, as well as to detect and appropriately respond to known predators, has led many to suggest that the survival of hatchery-raised fishes may be improved by exposing these fishes to predator odor in conjunction with an alarm cue prior to placement into a natural environment (Brown \& Laland 2001, Fernö et al. 2011). However, there is mixed support regarding whether predator recognition training increases survival (Berejikian et al. 1999, Hawkins et al. 2007, D'Anna et al. 2012, Wahl et al. 2012).

Recently, the length of time fishes retain learned associations has been hypothesized to affect the efficacy of predator recognition training (Brown et al. 2013). The few studies that have investigated the duration of leaned associations reported high variation between species. Hatchery-reared rainbow trout Onchorynchus mykiss have been found to retain learned recognition of a novel predator up to $21 \mathrm{~d}$ after initial conditioning (Brown \& Smith 1998), while fathead minnows Pimephales promelas retained predator recognition for at least 2 mo (Chivers \& Smith 1994). Fish are not alone in forgetting previously learned predator cues; several species of crayfish and tadpoles have also been shown to eventually forget previously learned predator cues in the absence of reinforcement of the cue (Hazlett et al. 2002, Gonzalo et al. 2009, Ferrari et al. 2010a). The tendency of animals to apparently forget previously learned predator cues led Ferrari et al. (2010a) to suggest a model of 'adaptive forgetting'. In their model, Ferrari et al. (2010a) propose that there is a high cost for misinterpreting predator cues, and as a result there is a strong inducement to retain only the most recent and/or reliable information. Brown et al. (2013) suggest that hatcheries select for many of the intrinsic factors that decrease the length of time fishes retain learned associations, and therefore reduce the efficacy of predator recognition training.
The June sucker Chasmistes liorus liorus (hereafter referred to as sucker) is an endangered fish endemic to Utah Lake, Utah (Whitney \& Belk 2000). Utah Lake once supported a community of 13 native fishes (Miller \& Crowl 2006); however, all but 2 native fishes have now been extirpated from the lake, and 16 non-native fishes (including many top-level predators) have been introduced (Table 1; Whitney \& Belk 2000, Belk et al. 2001, Billman \& Crowl 2007). A sucker captive propagation program has been in place for over a decade, although few of the hatchery-raised fish have recruited into the natural spawning population. Of the 11579 sucker stocked into Utah Lake directly from the hatchery facility between 1994 and 2006, only 85 were subsequently detected on the spawning grounds (Billman et al. 2011). Non-native predators were identified in the

Table 1. Native and non-native fish communities of Utah Lake, Utah. For native species, current status is recorded as present if there is a currently recognized reproducing population in Utah Lake. Only non-native species with a reproducing population are included in the table. The year established represents the first record of the species in Utah Lake

Native species

June sucker Chasmistes liorus liorus

Utah sucker Catostomus ardens

Utah Lake sculpin Cottus echinatus

Bonneville cutthroat trout Onchorhynchus clarkii Utah

Least chub Iotichthys phlegethontis

Bonneville redside shiner Richardsonius

balteatus hydrophlox

Mottled sculpin Cottus bairdi

Leatherside chub Gila copei

Utah chub Gila atraria

Speckled dace Rhinichthys osculus Longnose cace Rhinichthys cataractae

Mountain whitefish Prosopium williamsoni

Mountain sucker Catostomus platyrhyncus

Non-native species

Black bullhead Ameiurus melas

Common carp Cyprinus carpio

Goldfish Carassius auratus

Green sunfish Lepomis cynellus

Bluegill sunfish Lepomis machrochirus

Largemouth bass micropterus salmoides

Black crappie Pomoxis nigromaculatus

Yellow perch Perca flavescens

Channel catfish Ictalurus punctatus

Smallmouth bass Micropterus dolomieu

Red shiner Cypinella lutrensis

Western mosquitofish Gambusia affinis

Walleye Sander vitreum

White bass Morone chrysops

Fathead minnow Pimephales promelas

Grass carp Ctenopharyngodon idella

Current
status
Present
Present
Absent
Absent

Absent
Absent

Absent
Absent
Absent
Absent
Absent
Absent
Absent
Year
established
1871
1881
1889
1890
1890
1890
1890
1890
1911
1912
1920
$\sim 1930$
1952
1956
1968
$\sim 1990$


sucker recovery plan as a primary threat to the species recovery (US Fish \& Wildlife Service 1999), and have been suggested as a factor limiting the success of the restocking program (Belk et al. 2001, Billman et al. 2011). In this study, we investigated the ability of the June sucker to retain the association of a novel predator's odor with danger. We determined if hatchery-raised sucker innately recognized the odor of a non-native predator that is now common in Utah Lake. Additionally, we conducted experiments to determine if sucker could detect chemical alarm cues in the odor of feces from a predator that had recently consumed sucker and, if so, if the sucker would then associate the predator's fecal odor with the threat of predation in the absence of sucker chemical alarm cue. Finally, we tested the length of time sucker retain any learned predator recognition.

\section{MATERIALS AND METHODS}

Experiments were conducted at the Utah State University Millville Aquatic Research Facility in Millville, Utah using local well water. Utah Division of Wildlife's Fisheries Experiment Station provided predator-naïve sucker, which had not encountered a predator in their lifetime. Largemouth bass Micropterus salmoides were captured from Mantua Reservoir, Mantua, Utah, and swordtail Xiphophorus helleri were purchased from commercial pet stores. All fish were kept on a natural light schedule.

Two experiments were conducted: the first (hereinafter chemical cue recognition experiment) was designed to test if sucker could recognize a threat conveyed by the odor of largemouth bass feces and/or respond to conspecific chemical cues in the predator's feces. The second experiment (hereinafter learning experiment) tested if sucker can use chemical cues to learn to associate a predator's fecal odor with danger and if so, how long they retain that association.

\section{Fright response}

Sucker were observed prior to the experiments to identify fright reaction behavior. During this observational period, fish were acclimated for $24 \mathrm{~h}$, at which time a small stone was dropped into the tank and the reaction of the fish was documented. Two fright reactions, dashing and freezing, were identified. Dashing was defined as rapid, undirected swimming, while freezing was defined as the cessation of all movement. Dashing and freezing are common fright reactions observed in many species of fishes (Chivers \& Smith 1998, Brown et al. 2001). Although no shoaling behavior was observed, initial trials revealed that groups smaller than 5 sucker did not acclimate to the experimental tanks; therefore, sucker were tested in groups of 5 for both experiments.

\section{Preparation of stimuli}

To collect sucker chemical alarm cues (AC), 4 sucker were pithed and filleted. The fillets were immediately homogenized with chilled distilled water at a concentration of $0.1 \mathrm{~cm}^{2}$ skin ml-1 $\mathrm{H}_{2} \mathrm{O}$. The mixture was filtered through glass wool, divided into $60 \mathrm{ml}$ aliquots, and frozen for future use. Sixty $\mathrm{ml}$ of stimulus created a concentration of $4 \times 10^{-4} \mathrm{ml}$ of stimulus per ml of experimental tank water, which is consistent with published methods (Brown et al. 2006).

Prey fishes can often detect predators and conspecific chemical cues from the feces of predators (Brown et al. 1995). To collect predator feces containing sucker chemical cue (hereinafter PFCC), 4 bass were fed sucker ad libitum for $10 \mathrm{~d}$. In order to collect predator feces without sucker chemical cue (hereinafter referred to as PF), 4 bass were fed swordtail ad libitum for $10 \mathrm{~d}$. The ability to detect chemical alarm cues is limited to closely related species and heterospecific species with a history of co-occurrence (Ferrari et al. 2010c). Sucker and swordtail are neither closely related nor do they co-occur; therefore there was no reason to suspect that swordtail alarm cue would elicit a fright response in sucker. On Day 10, $1 \mathrm{~h}$ after feeding, the bass were removed from their holding tank, rinsed with distilled water, and placed into $150 \mathrm{l}$ aerated, unfiltered tanks by feeding history, so that that all bass previously fed sucker were placed into one tank and all bass previously fed swordtail were placed into another. After $24 \mathrm{~h}$, the bass were removed. The water and feces were siphoned from the bottom of the tank, mixed, and frozen in $60 \mathrm{ml}$ aliquots for use as PFCC or PF stimulus.

\section{Behavioral trials}

The methods for behavioral trials were identical for both experiments. Behavioral trials were conducted in four $150 \mathrm{l}$ aerated but unfiltered tanks, with water temperature kept between 18 and $21^{\circ} \mathrm{C}$. The experimental tanks were encircled with a curtain to remove any visual stimuli, and an opaque barrier was used to visually separate the tanks. Plastic tubing $(1 \mathrm{~m}$ in 
length, $0.25 \mathrm{~cm}$ inside diam.) was secured to the airstone tubing and extended through the curtain. This tube was used to inject stimulus or control water during the trial. Tanks were drained, rinsed, dried, and refilled between each trial. Trials were videorecorded, and behavioral analysis was conducted from the recording using Observer $\mathrm{XT}^{\circledR}$ software.

Five 1 yr old, predator-naïve sucker were placed into each tank and allowed to acclimate for $24 \mathrm{~h}$. Prior to the start of each trial, $120 \mathrm{ml}$ of water was drawn out of the tank through the injection hose with a syringe. The first $60 \mathrm{ml}$ was discarded, and the remainder was kept to flush the stimulus completely through the tube. All behavioral trials were $10 \mathrm{~min}$ in duration, and divided into two 5 min time periods. The stimulus was injected into the tank exactly $5 \mathrm{~min}$ into the trial, marking the end of the pre-exposure period and the beginning of the post-exposure period. In order to control for any inherent differences in behavior between tanks, we calculated the response variables (time spent dashing and time spent freezing) by subtracting pre-exposure values from post-exposure values for each individual trial.

\section{Chemical cue recognition experiment}

The 4 treatments (AC, $\mathrm{PF}, \mathrm{PFCC}$, and control) were replicated 12 times. Within each trial, treatments were randomized among tanks. Behavioral trials were conducted in 2 blocks with 8 trials conducted between 10 and 17 November 2007, and the remaining 4 trials conducted between 14 and 17 March 2008. A total of 240 sucker were used (mean standard length [SL] $=177.34 \pm 25.99 \mathrm{~mm}$ ). The length of fish was consistent with those routinely stocked into Utah Lake as part of the captive propagation program. Each fish was used only once to avoid any learning bias.

Each behavioral response was individually compared using a 2-way ANOVA to test for differences between the treatments while accounting for any difference due to experimental block. Time spent dashing and freezing were both $\log _{10}$ transformed to meet the assumption of normality and stabilize residuals. Post hoc mean comparisons were done using Tukey's HSD test. All analyses were performed with $\mathrm{R}$ version 3.0.1 (R Development Core Team 2013).

\section{Learning experiment}

A total of $1601 \mathrm{yr}$ old suckers (mean SL $=198.29 \pm$ $25.28 \mathrm{~mm}$ ) were exposed in $230 \mathrm{l}$ tanks to either the
PF stimulus (hereinafter condition control, $\mathrm{n}=80$ fish) or PFCC stimulus (hereinafter conditioned, $\mathrm{n}=80$ fish). Fish were not re-used from the AC recognition experiment. Flow was temporarily stopped and $240 \mathrm{ml}$ of the appropriate stimulus was added to the tank, creating a concentration of $0.001 \mathrm{ml}$ stimulus $\mathrm{ml}^{-1}$ of tank water. The concentration of stimulus was higher than that used in the first trial to ensure detection by all fish. After 30 min, flow was resumed.

Two days after initial exposure, half the fish from each exposure history (40 fish; 8 trials per exposure history) were tested for an association between largemouth bass and predation risk using the behavioral trials described above. In these trials, all fish were exposed to the PF stimulus. We followed the same procedure with the remaining fish $10 \mathrm{~d}$ after initial exposure. Sucker were initially exposed to either PF or PFCC stimulus on 14 July 2008, and behavioral trials were conducted on 16 and 24 July 2008.

Behavioral variables were compared between exposure history and days since exposure using a 2-way ANOVA with Tukey's HSD used for post-hoc comparisons.

\section{RESULTS}

\section{Chemical cue recognition experiment}

The behavior of the fish did not differ significantly between the 2 trial blocks (time spent dashing: $F_{1,40}=$ 2.16, $\mathrm{p}=0.15$; time spent freezing: $F_{1,40}=0.34, \mathrm{p}=$ $0.57)$. There were significant differences between the treatments in time spent dashing $\left(F_{3,44}=18.73\right.$, $\mathrm{p}<0.0001$; Fig. 1). AC elicited the highest levels of dashing behavior compared to all other treatments (pairwise Tukey-adjusted p-values $<0.03$ between $\mathrm{AC}$ and all other treatments). Sucker exposed to PFCC exhibited dashing behavior 15 times higher than those exposed to PF (Tukey-adjusted $p=0.01$ ). Exposure to bass odor alone did not result in higher levels of time spent dashing (Tukey-adjusted $\mathrm{p}=$ 0.96 ; Fig. 1) than the control. Time spent freezing was not significantly different among treatments $\left(F_{3,40}=\right.$ $0.71, \mathrm{p}=0.55)$.

\section{Learning experiment}

Two days after exposure, conditioned sucker showed recognition of bass odor as a threat (time spent freezing, $F_{1,28}=8.024, \mathrm{p}<0.01$, conditioned vs. condition control at $2 \mathrm{~d}$, Tukey-adjusted $\mathrm{p}=0.01$; Fig. 2). By 


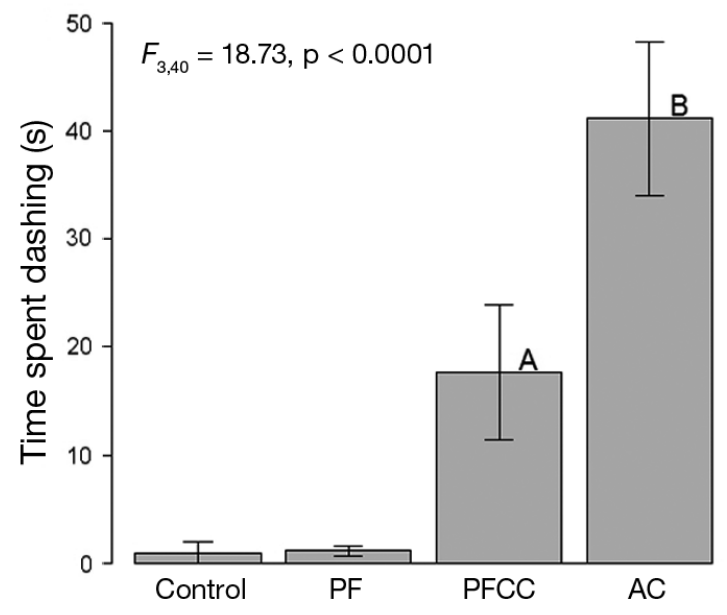

Fig. 1. Chasmistes liorus. Time spent dashing (mean $\pm \mathrm{SE}$ ) by treatment in the alarm cue recognition experiment. Time spent dashing was calculated by subtracting pre-exposure from post-exposure values for each trial. Significance was determined using ANOVA $\left(F_{3,40}=18.73, \mathrm{p}<0.0001\right)$. Letters above bars indicate significant differences among treatments identified by Tukey-adjusted post hoc mean comparison $(\mathrm{p} \leq 0.03) . \mathrm{PF}=$ predator feces, $\mathrm{PFCC}=$ predator feces + June sucker chemical cue, AC = alarm cue

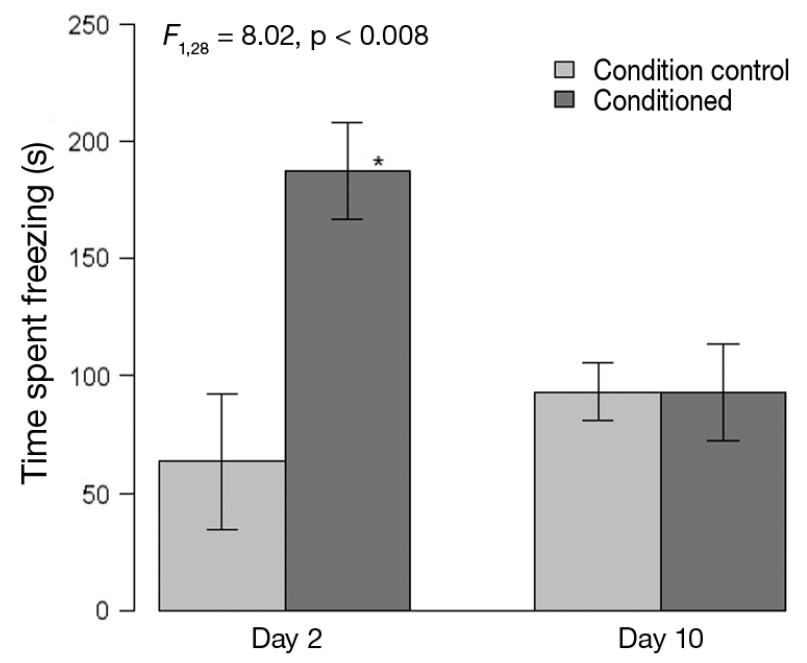

Fig. 2. Chasmistes liorus. Time spent freezing (mean $\pm \mathrm{SE}$ ) by exposure history after 2 and $10 \mathrm{~d}$ in the learning experiment. Time spent freezing was calculated by subtracting pre-exposure from post-exposure values for each trial. Significance was determined using ANOVA $\left(F_{1,28}=8.02, \mathrm{p}=\right.$ 0.008). The asterisk above the bar indicates significant differences among treatments identified by Tukey post hoc test $(p=0.01)$

Day 10, conditioned sucker no longer showed any recognition of bass odor (conditioned vs. condition control at $10 \mathrm{~d}$, Tukey-adjusted $\mathrm{p}=0.92$ ). Freezing behavior of condition control sucker was similar between Days 2 and 10 (Tukey-adjusted $p=0.14$ ). Time spent dashing was not significantly different between conditioned versus condition control sucker at any time $\left(F_{1,28}=0.49, \mathrm{p}=0.49\right)$. Condition control sucker at Day 2 and sucker from both exposure histories at Day 10 did spend a significant amount of time freezing (all p-values <0.02). However, the amount of time spent freezing was not significantly different than the control treatment in the chemical cue recognition experiment $\left(F_{4,43}=0.93, \mathrm{p}=0.46\right)$.

\section{DISCUSSION}

The production of a chemical alarm cue, recognition of odors associated with this cue, and the ability to relate those odors to danger are all necessary for fishes to identify novel predation threats through olfaction. We showed that sucker can recognize conspecific chemical cues in the odor of a predator that has recently eaten sucker, and form temporary associations between that predator's odor and predation threat. However, we also showed that sucker no longer display any behavioral evidence of this learned association after $10 \mathrm{~d}$.

Although the feces of the largemouth bass that had consumed sucker did elicit a significant fright response, fish exposed to $\mathrm{AC}$ alone showed the strongest fright response. One possible explanation for this difference in response is that the concentration of alarm cue was likely higher in the AC-only stimulus. Concentration of chemical alarm cue may serve as an indicator of the proximity of the predation event or the level of threat posed by an approaching predator (Mirza \& Chivers 2003, Zhao et al. 2006). If cue concentration does convey information about proximity or threat level, a stimulus that contains a higher concentration of the alarm cue would be expected to elicit higher levels of fright response. Zhao et al. (2006) found that the fright response of goldfish Carassius auratus to pike odor and goldfish alarm cue increased as the concentration of the stimulus was increased. Additionally, it is unknown how digestive processes affect the chemical structure of the alarm cue, although it is reasonable to assume that the chemical cue present in the feces has a slightly different structure, which may convey a less immediate threat to conspecifics.

Regardless of the cause of the decrease in dashing behavior between fish exposed to AC only and those exposed to predator feces from fish fed sucker, both stimuli elicited a fright response significantly higher than the control. However, exposing sucker to predator feces alone did not elicit a significant fright 
response. The failure of bass feces alone to prompt a fright response significantly different than the control indicates that predator-naïve sucker do not innately recognize a threat in largemouth bass feces. This suggests that any significant fright response seen in the learning experiment should be attributable to a learned association between predator feces odor and danger.

Although the fright response switched from dashing to freezing behavior in the learning experiment, our results showed sucker can learn to associate largemouth bass fecal odor with the threat of predation. The cause of the switch from dashing to freezing behavior is unclear. A potential explanation is that the stimulus used to condition the sucker potentially conveyed a lower perceived threat than exposure to undigested AC. The threat level conveyed by the conditioning stimulus combined with the absence of any visual or chemical reinforcement may have led to a level of uncertainty regarding the threat conveyed by predator feces, which manifested itself as a more conservative fright response (Ferrari et al. 2012).

June sucker showed a learned recognition of a threat conveyed by largemouth bass feces $2 \mathrm{~d}$ after initial conditioning. Although there was no difference between conditioned and condition control fish at Day 10, both groups of fish did spend a significant amount of time freezing. While this implies a small fright response, their response was not different from the control treatment in the chemical cue recognition experiment. The inclusion of a true control in the learning experiment would have increased the confidence in our results. Another factor that cannot be discounted is the possibility that social learning occurring during the batch conditioning may have influenced the results seen on Day 2 of the learning experiment (Brown \& Laland 2001, 2003). The addition of multiple conditioning batches would have strengthened the interpretation of our results. However, as conducted, our experiment shows that $10 \mathrm{~d}$ after conditioning there was no longer evidence that sucker retained the association between predator feces and danger. Length of retention has been shown to vary with the strength of threat conveyed during conditioning (Ferrari et al. 2010b). As discussed above, there may have been a low perceived risk conveyed by the stimuli used to condition the sucker. Additionally, the hatchery environment is typically designed to maximize growth rate (Johnsson et al. 1996), which is negatively associated with the length of memory retention (Brown et al. 2011b, 2013). Consequently, the rearing environment of captively propagated fishes may result in a predispo- sition to forget predator cues more quickly. It is worth mentioning that our study (and others like it), cannot actually distinguish between fish that have forgotten the predator cue and those that have discounted the quality of the cue to a level whereby responding to the cue is no longer advantageous (Ferrari et al. 2010a). However, the behavioral response, and therefore the survival benefit conferred, is the same regardless if the fish has forgotten or discounted the cue.

The ability of fish to forget predator cues makes sense considering the large number of odors to which fish are exposed in the natural environment. There would be a variety of odors present at any given time in addition to the predator odor and alarm cue (Ferrari et al. 2010c). Additionally, many fish predators are gape limited, and prey can outgrow their vulnerability to these predators (Brown et al. 2011b, 2013). In their model of 'adaptive forgetting', Ferrari et al. (2010a) proposed that it would not be advantageous to form a permanent association between every odor present and danger after a single exposure to a conspecific alarm cue. Therefore, fish may retain a short association, and in the absence of reinforcement or as the fish grows, the association may disappear.

A June sucker restocking program has been in effect for over a decade, though few stocked fish have appeared in the spawning population-likely due to predation by non-native fishes (Billman et al. 2011). Low survival of hatchery-reared fish is a commonly reported problem for many captive propagation programs, especially those operating in systems with large native and/or non-native predator populations (Salvanes \& Braithwaite 2006). For example, Shively et al. (1996) found that newly released, hatchery-reared Chinook salmon Oncorhynchus tshawytscha comprised the majority of the diet of a native predator (the northern squawfish Ptychocheilus oregonensis) up to $1 \mathrm{wk}$ after hatchery releases. The widespread nature of predation in reducing the effectiveness of stocking programs has led to a rich body of research focused on the ability of prey to learn to recognize novel predator odors (reviewed in Brown et al. 2011a). However, the results of studies investigating the effectiveness of predator recognition training are mixed (Hawkins et al. 2007, Wahl et al. 2012). For example, Berejikian et al. (1999) found that predator recognition training did not improve survival of Chinook salmon. While D'Anna et al. (2012) found that white seabream Diplodus sargus trained to recognize predators were nearly twice as likely to survive as their predator-naïve counterparts. Brown et al. (2013) suggested that the reason for these mixed results may be linked to the length of 
time the different study species retain learned associations. With this in mind, our results suggest that using chemical cues to train hatchery-raised sucker to recognize and correctly respond to predators prior to stocking into a non-native predator rich environment may not be effective. Although sucker do recognize a conspecific chemical alarm cue both alone and in the feces of a predator that has consumed sucker, and can learn to recognize the odor of a predator's feces, the length of time they retain this association is likely insufficient to convey any poststocking survival benefits (Brown et al. 2013). However, increasing the threat conveyed by the conditioning stimulus by pairing predator odor with fresh alarm cue may increase the length of time sucker retain the association, potentially increasing the usefulness of chemical cue training for the captive propagation program (Kraft 2009, Ferrari et al. 2010a). Additionally, the non-native predator community in Utah Lake is now diverse (Table 1; Whitney \& Belk 2000, Belk et al. 2001, Miller \& Crowl 2006); therefore, research should be conducted to address the effectiveness of training sucker to recognize multiple predator cues.

Acknowledgements. We thank our funding sources: the Utah chapter of the American Fisheries Society, the Ecology Center at Utah State University, and the Presidential Fellowship at Utah State University. We also thank C. P. Hawking, K. A. Sullivan, C. A. Layman, and the anonymous reviewers who provided invaluable comments and support in the preparation of this manuscript.

\section{LITERATURE CITED}

Araki H, Cooper B, Blouin MS (2007) Genetic effects of captive breeding cause a rapid, cumulative fitness decline in the wild. Science 318:100-103

> Bearlin AR, Schreiber ESG, Nicol SJ, Starfield AM, Todd CR (2002) Identifying the weakest link: simulating adaptive management of the reintroduction of a threatened fish. Can J Fish Aquat Sci 59:1709-1716

Belk MC, Whitney MJ, Schaalje GB (2001) Complex effects of predators: determining vulnerability of the endangered June sucker to an introduced predator. Anim Conserv 4:251-256

Berejikian BA (1995) The effects of hatchery and wild ancestry and experience on the relative ability of steelhead trout fry (Oncorhynchus mykiss) to avoid a benthic predator. Can J Fish Aquat Sci 52:2476-2482

Berejikian BA, Smith RJF, Tezak EP, Schroder SL, Knudsen CM (1999) Chemical alarm signals and complex hatchery rearing habitats affect antipredator behavior and survival of Chinook salmon (Oncorhynchus tshawytscha) juveniles. Can J Fish Aquat Sci 56:830-838

Billman EJ, Crowl TA (2007) Population dynamics of a June sucker refuge population. Trans Am Fish Soc 136:959-965 Billman EJ, Rasmussen JE, Watson J (2011) Evaluation of release strategies for captive-reared June sucker based on poststocking survival. West N Am Nat 71:481-489

> Brown C, Laland K (2001) Social learning and life skills training for hatchery reared fish. J Fish Biol 59:471-493

> Brown C, Laland K (2003) Social learning in fishes: a review. Fish Fish 4:280-288

> Brown GE, Smith RJF (1998) Acquired predator recognition in juvenile rainbow trout (Oncorhynchus mykiss): conditioning hatchery-reared fish to recognize chemical cues of a predator. Can J Fish Aquat Sci 55:611-617

Brown GE, Chivers DP, Smith RJF (1995) Fathead minnows avoid conspecific and heterospecific alarm pheromones in the feces of northern pike. J Fish Biol 47:387-393

Brown GE, Adrian JC, Shih ML (2001) Behavioural responses of fathead minnows to hypoxanthine-3-N-oxide at varying concentrations. J Fish Biol 58:1465-1470

Brown GE, Bongiorno T, DiCapua DM, Ivan LI, Roh E (2006) Effects of group size on the threat-sensitive response to varying concentrations of chemical alarm cues by juvenile convict cichlids. Can J Zool 84:1-8

Brown GE, Ferrari MC, Chivers DP (2011a) Learning about danger: chemical alarm cues and threat-sensitive assessment of predation risk by fishes. In: Brown C, Laland $\mathrm{K}$, Krause J (eds) Fish cognition and behavior, 2nd edn. Wiley-Blackwell, Oxford, p 59-80

Brown GE, Ferrari MCO, Malka PH, Oligny MA, Romano M, Chivers DP (2011b) Growth rate and retention of learned predator cues by juvenile rainbow trout: fastergrowing fish forget sooner. Behav Ecol Sociobiol 65: 1267-1276

> Brown GE, Ferrari MCO, Chivers DP (2013) Adaptive forgetting: why predator recognition training might not enhance poststocking survival. Fisheries 38:16-25

Bruton MN (1995) Have fishes had their chips? The dilemma of threatened fishes. Environ Biol Fishes 43:1-27

Chivers DP, Smith RJF (1994) Fathead minnows, Pimephales promelas, acquire predator recognition when alarm substance is associated with the sight of unfamiliar fish. Anim Behav 48:597-605

Chivers DP, Smith RJF (1998) Chemical alarm signalling in aquatic predator-prey systems: a review and prospectus. Ecoscience 5:338-352

> D'Anna G, Giacalone VM, Vega Fernández T, Vaccaro AM and others (2012) Effects of predator and shelter conditioning on hatchery-reared white seabream Diplodus sargus (L., 1758) released at sea. Aquaculture 356-357: 91-97

> Dextrase AJ, Mandrak NE (2006) Impacts of alien invasive species on freshwater fauna at risk in Canada. Biol Invasions 8:13-24

Fernö A, Huse G, Jakobsen PJ, Kristiansen TS, Nilsson J (2011) Fish behaviour, learning, aquaculture and fisheries. In: Brown C, Laland K, Krause J (eds) Fish cognition and behavior, 2nd edn. Wiley-Blackwell, Oxford, p 359-404

> Ferrari MCO, Brown GE, Bortolotti GR, Chivers DP (2010a) Linking predator risk and uncertainty to adaptive forgetting: a theoretical framework and empirical test using tadpoles. Proc Biol Sci 277:2205-2210

> Ferrari MCO, Brown GE, Jackson CD, Malka PH, Chivers DP (2010b) Differential retention of predator recognition by juvenile rainbow trout. Behaviour 147:1791-1802

Ferrari MCO, Wisenden BD, Chivers DP (2010c) Chemical ecology of predator-prey interactions in aquatic ecosystems: a review and prospectus. Can J Zool 88:698-724 
Ferrari MCO, Vrt lová J, Brown G, Chivers D (2012) Understanding the role of uncertainty on learning and retention of predator information. Anim Cogn 15:807-813

US Fish \& Wildlife Service (1999) June Sucker (Chasmistes liorus) recovery plan. US Fish \& Wildlife Service, Denver, $\mathrm{CO}$

Gonzalo A, Lopez P, Martin J (2009) Learning, memorizing and apparent forgetting of chemical cues from new predators by Iberian green frog tadpoles. Anim Cogn 12: 745-750

Hawkins LA, Armstrong JD, Magurran AE (2007) A test of how predator conditioning influences survival of hatchery-reared Atlantic salmon, Salmo salar, in restocking programmes. Fish Manag Ecol 14:291-293

Hazlett BA, Acquistapace P, Gherardi F (2002) Differences in memory capabilities in invasive and native crayfish. J Crustac Biol 22:439-448

Helfman GS (2007) Fish conservation: a guide to understanding and restoring global aquatic biodiversity and fishery resources. Island Press, Washington, DC

Johnsson JI, Petersson E, Jonsson E, Bjornsson BT, Jarvi T (1996) Domestication and growth hormone alter antipredator behaviour and growth patterns in juvenile brown trout, Salmo trutta. Can J Fish Aquat Sci 53:1546-1554

Kraft SA (2009) Naive prey versus nonnative predators: a role for behavior in endangered species conservation. MSc Thesis, Utah State University, Logan, UT

Marsh PC, Brooks JE (1989) Predation by Ictalurid catfishes as a deterrent to re-establishment of hatchery-reared razorback suckers. Southwest Nat 34:188-195

Miller SA, Crowl TA (2006) Effects of common carp (Cyprinus carpio) on macrophytes and invertebrate communities in a shallow lake. Freshw Biol 51:85-94

Mirza RS, Chivers DP (2003) Response of juvenile rainbow trout to varying concentrations of chemical alarm cue: response thresholds and survival during encounters with predators. Can J Zool 81:88-95

Pearsons TN, Fritts AL, Scott JL (2007) The effects of hatchery domestication on competitive dominance of juvenile

Editorial responsibility: Benjamin Ruttenberg,

Palmetto Bay, Florida, USA spring Chinook salmon (Oncorhynchus tshawytscha). Can J Fish Aquat Sci 64:803-812

> Pfeiffer W (1967) Fright reaction and alarm substance cells in Ostariophysi and Gonorhynchiformes. Z Vgl Physiol 56:380-396

R Development Core Team (2013) R: a language and environment for statistical computing. R Foundation for Statistical Computing, Vienna

Rakes PL, Shute JR, Shute PW (1999) Reproductive behavior, captive breeding, and restoration ecology of endangered fishes. Environ Biol Fishes 55:31-42

Salvanes AGV, Braithwaite V (2006) The need to understand the behaviour of fish reared for mariculture or restocking. ICES J Mar Sci 63:345-354

Shively RS, Poe TP, Sauter ST (1996) Feeding response by northern squawfish to a hatchery release of juvenile salmonids in the Clearwater River, Idaho. Trans Am Fish Soc 125:230-236

von Frisch K (1938) Zur Psychologie des Fish-Schwarmes. Naturwissenschaften 26:601-606

von Frisch K (1942) Über einen Schreckstoff der Fischhaut und seine biologische Bedeutung. Z Vgl Physiol 29: 46-145

Wahl DH, Einfalt LM, Wojcieszak DB (2012) Effect of experience with predators on the behavior and survival of muskellunge and tiger muskellunge. Trans Am Fish Soc 141:139-146

Whitney M, Belk MC (2000) Threatened fishes of the world: Chasmistes liorus Jordan, 1878 (Catostomidae). Environ Biol Fishes 57:362

Yokota T, Masuda R, Arai N, Mitamura H, Mitsunaga Y, Takeuchi H, Tsuzaki T (2007) Hatchery-reared fish have less consistent behavioral pattern compared to wild individuals, exemplified by red tilefish studied using video observation and acoustic telemetry tracking. Hydrobiologia 582:109-120

- Zhao XX, Ferrari MCO, Chivers DP (2006) Threat-sensitive learning of predator odours by a prey fish. Behaviour 143:1103-1121

Submitted: January 11, 2013; Accepted: January 9, 2014 Proofs received from author(s): March 21, 2014 